\title{
The Research of Multidimensional Interactive Teaching for College English
}

\begin{abstract}
CHEN Meng-jie, SHI Xi-chun
Changchun University, Changchun, China

College English class under multimedia environment is inseparable from the mode of interactive teaching, Multimedia is an effective method to cultivate students' proficiency of using English. College English teachers should find a mode of interactive teaching suitable for the students and themselves taking such effective measures as changing the conception, optimizing the teaching, successfully designing the teaching task, etc. In this way, guide students to participate in classroom activities actively, thus to achieve the purpose of teaching.

Keywords: multimedia, interactive, language skills
\end{abstract}

\section{Introduction}

Since the reform and opening up, China has entered into the world trade organization. In the development of the economic globalization, English has become an important tool for language communication. At the same time, the multimedia interactive model of college English teaching has been widely used, which not only brings a lot of changes to the interaction between teachers and students, but also activates the classroom atmosphere, and arouses great interest in learning English. However, from the current situation of college English multimedia interactive teaching mode, there are still a lot of problems, which seriously affect the quality of college English teaching. In view of the current situation of college English multimedia interactive teaching mode, this paper will discuss some suggestions for improvement.

\section{Interactive and Interactive Teaching Mode}

In the field of English education, many experts have made research on the "interaction". WU Bian (2008) thinks that "knowledge is the result of the gradual construction of the individual in the process of interacting with the environment" (pp. 51-53). HE Gao-da (2012) believes that the interaction is a process where two or more people exchange ideas and feelings, and transmit information, finally making an impact on both sides (pp. 23-27). SHAN Wei-hong (2005) considers that "interaction" is a "cooperative activity' in the establishment of three sides of the issue of information sender, receiver and language environment" (pp. 122-124). According to all above, we can know that the classroom interaction is a process of mutual influence between teachers and students, students and students, which is an important index to evaluate the classroom teaching and the teaching quality.

CHEN Meng-jie, lecturer, master, Public Foreign Language Teaching and Research Department, Changchun University. SHI Xi-chun, lecturer, master, Public Foreign Language Teaching and Research Department, Changchun University. 
The main goal of college English teaching is to cultivate college students' comprehensive use ability of English, which needs a large number of cultivation. College English classroom is the main opportunity of language practice. The interactive teaching mode between teachers and students rising in recent years emphasizes the students as the main body of teaching ideas. This teaching mode increases the opportunities for students to express real feelings, transfer information and other language practice, which stimulates students to participate in classroom teaching activities, and the initiative to meet the students' cognitive and emotional, as well as gives full play to students' autonomy, participation, and creativity. At last, it promotes the students to become the subject of English learning and the constructor of the knowledge meaning.

Interactive teaching mode is the premise and guarantee of improving college English teaching quality and promoting the success of college English teaching. College English teachers should pay more attention to and use the interactive teaching mode to guide students to participate actively and experience the whole process of college English teaching, so as to achieve the purpose of increasing the accumulation of language and improving the ability of language application.

\section{The Significance and Teaching Errors of the Multimedia Teaching}

Multimedia is to use computer to deal with a variety of media information (such as data, images, video, audio, etc.), thus finishing the establishment of a logical connection and the integration of a system of computer technology. The multimedia computer not only makes the acquisition and support of the diversity knowledge in classroom teaching possible, but also realizes the most effective function of organization and management of teaching information to create the ideal environment for learning. College English classroom teaching in the multimedia environment constructs a high quality teaching environment for learners. The teaching of college English with the aid of multimedia environment has the characteristics of scientific, interactive, integrated, rich, nonlinear, diagnostic, hypermedia, multimedia, intelligent, situation, virtualization, and so on.

In recent years, the multimedia technology in college English teaching has been fully utilized and the traditional blackboard teaching mode of English has been completely changed. More and more college English teachers use multimedia to assist in teaching, not only enter a higher quality of information in the limited teaching time, but also provide students with a new language environment, which is conducive to the cultivation of students' learning interest and improvement of their listening and speaking ability.

Multimedia has brought the reform of college English teaching, but also the new problems. In practice of the multimedia classroom, people often can see this situation: There is dim light in the multimedia classroom with the slides full of dense English words. The teacher plays as the courseware playing and instructors, while students quietly staring at the screen carrying head are not necessarily listening to the teacher. Although students get enough high quality corpus input in the classroom teaching under the multimedia environment, they still do not have full opportunities for sufficient language output. It optimizes the methods and ways of English teaching, but also reduces the teacher's dominant position, and encourages the students to learn inert, finally the language use ability of them cannot be improved; "dumb English" and other issues still cannot be solved. How to make the multimedia environment full used of its role in the teaching is worthy of in-depth study for college English teachers. 


\section{Interactive Strategy of College English Teaching Under the Multimedia Environment}

Although very advanced the multimedia technology is, it cannot completely replace the role of teachers in college English teaching. In order to make the classroom teaching successful, college English teachers must mobilize their own subjective initiative, combine the advantages of multimedia technology and interactive teaching mode with students and students to create a new teaching mode. To do this, the university English teachers must pay attention to the following aspects.

\section{Change Idea}

The college English teaching under the multimedia environment has put forward new challenges to college English teachers. It requires teachers not only to be proficient in college English teaching and teaching mode with a certain teaching ability, but also to know a certain computer, network technology, as well as how to make full use of computer and network for college English teaching. In addition, college students living in this information era are always contact with all kinds of English learning website, audio-visual materials, teaching Compact Disc Read-Only Memory (CD-ROM), electronic lesson plans, and detailed teaching reference books; these also put forward new requirements for college English teachers. They are no longer satisfied with the traditional teaching methods of college English teachers as well as a detailed explanation of the contents of the textbooks. They hope that college English teachers have a higher professional quality and certain information technology; they also hope that teachers reform teaching methods and teaching content in order to give positive and correct guidance to them. Besides that, the students hope they cannot only learn knowledge, but also have more language practice opportunities in the classroom. In the multimedia environment of the classroom teaching, teachers should reposition the role of themselves as a guide, information provider, and classroom manager. Pay attention to and focus on the cultivation of students' autonomy. Pay attention to and provide students with the opportunity to provide adequate English output, and develop students' ability to monitor and adjust themselves in the process of learning.

\section{Optimize Classroom Teaching}

To make the interaction of college English teaching in the multimedia environment successful, the teachers should optimize the classroom scene teaching, and promote the students' interest in English learning combined with the extracurricular activities. For these Chinese college students who lack oral environment in the life, especially the local college students, college English class is still the main opportunity for them to carry on the language input and output, and to cultivate the comprehensive ability of using English. Therefore, it is very important for students' study initiative and interest. College English teachers should make full use of the advantages of computer and network information to design each class, and provide students with a pleasant audio-visual interactive language environment. For teaching content, college English teachers should try to use authentic or close to the real corpus materials, and make more practice, so as to make full use of a variety of interactive activities through teachers and students, and guide students to participate in the initiative activities to easily output the oral language. Thus achieving the purpose of learning and using language.

\section{Pay Attention to the Design of the Teaching Task}

In actual teaching, people find that most students enter the classroom with the expectation of mastering the quality and quantity of study. Therefore, the teaching and the design of the teaching task by English teachers in 
class directly affect the success of classroom interaction. The design of classroom teaching task has a decisive effect on the teaching quality. Therefore, teachers should study the teaching materials combining with the existing English foundation, psychological characteristics, and the law of language learning before class, so as to mobilize the students' learning interest, meet the needs of students making enthusiasm and active students' thinking as the purpose, and design a good classroom teaching and learning task. The success of a teaching task is helpful to mobilize the students' to learning confidence, autonomy, and interest. Besides that, a good classroom teaching task is also conducive to the rational thinking of the students. Before class, the teachers tell the students about the teaching task and learning materials related to the task, so that students have enough time to prepare and think about. Only the preparation has been well made, will the students' confidence in the classroom learning be enough, will the probability of success of the classroom task be also big, and will their learning motivation be stronger.

\section{Pay Attention to the Use of Communicative Teaching Strategy}

Communicative teaching method is a kind of teaching method which is beneficial to improve the teaching method, as well as a guarantee to the success of the teaching. It advocates to pay attention to the actual needs of students, and pays attention to the students properly use the language communication in a certain context. Communication is an effective way for learners to master and learn to use the intermediary language. Communication strategy is one of the important factors in the formation and development of the intermediary language. It can promote the formation of English learners on the knowledge of the hypothesis, verification, and automation of knowledge. The students will get the language input of good quality, and their confidence of overcoming the anxiety will also increase, so that the language exchange will be more smooth. Even the best learners in the English language will fail to communicate with others because of lack of communication strategies. So that it is necessary to understand the communicative strategies for students who want to freely communicate with others in a certain context.

Under the interactive teaching in the multimedia environment, the teachers can make use of the scene to play the roles of the play to make the students know and master some of the negative, and help them know more other common communication strategies. The students understanding "when to say" and "how to say" will actively participate in the classroom teaching activities, communicate with others, and finish the language output. With more output opportunities, there will be no "dumb English".

\section{Conclusion}

College English classroom cannot be separated from the interactive teaching mode, which is an effective way to cultivate students' language ability and improve students' cultural quality and comprehensive ability, as well as the teaching quality. College English teachers should actively seek for their own and the students' teaching interaction model, and guide students to actively participate in the activities of the classroom, so as to achieve the purpose of improving the comprehensive use of language.

\section{References}

CUI, L. (2004). Multimedia projection of college English classroom teaching mode: Analysis of STudents' character. Foreign Language World, 53(19), 41-48. 
HE, G. D. (2012). Multimedia technology—Revolution of cross-cultural communication. Journal of Sichuan Foreign Language Institute, 36(25), 23-27.

SHAN, W. H. (2005). Complementary advantages of modern information technology and traditional method in higher education. Journal of East China Transportation University, 64(17), 122-124.

SHU, D. F., \& WANG, H. D. (2004). Rethinking of the function and location of foreign language classroom teaching. Foreign Languages and Foreign Teaching, 29(8), 3-6.

WU, B. (2008). Focus on the interactive teaching mode, improve college classroom efficiency. Science Education Front, 78(12), 51-53.

YANG, X. Y. (2013). The review of west research about foreign language classroom process. Foreign Teaching, 67(23), 34-36.

ZHANG, Z. Z. (2012). Research on the interactive teaching mode based on the multimedia. Journal of Hubei Finance and Economics College, 41(21), 56-58.

ZHUANG, Z. X., HUANG, W., \& WANG, L. (2007). Present situation and prospect of multimedia foreign language teaching in China. Foreign Language Audio-Visual Teaching, 69(15), 20-27. 